Further investigations on the new macrofossil structures are in progress together with work on the microfossil structures and the organic compounds.

\title{
Reference
}

Bondesen, E. , Pedersen, K. Raunsgaard and Jørgensen, O. (in press) Precambrian organisms and the isotopic composition of organic remains in the Ketilidian of South-West Greenland. Medd. Grфnland, Bd. 164, Nr. 4.

\section{ULTRABASIC INTRUSIVES FROM NARSSAQ AND TUGTUTÔQ}

\section{B. G. J. Upton}

On the Panernaq peninsula [now named Ungussivik] north of Narssaq, five small outcrops of ultrabasic rock occur, the largest being some $200 \mathrm{~m}$ across. Conceivably these are connected at depth and should be regarded as probably comprising a single intrusion. The smallest (southernmost) of the outcrops is now, unfortunately, obscured by a Narssaq municipal refuse-tip. Two small bodies of similar ultrabasic material have been found on the eastern part of Tugtutô island. All these ultrabasic masses are associated with the large olivine gabbro intrusions (Upton, 1964) and are held to represent younger intrusions into, or adjacent to, the latter. They are themselves cut by the big feldspar dykes and by the trachyte and comendite dykes of the regional WSW-ENE swarms.

Typically these ultrabasic and ultramafic masses are composed of fine-grained rock with a hornfelsic appearance. The texture is generally decussate and equigranular with an average grain size of around $0.25 \mathrm{~mm}$. The colour is variable from black, brown, yellowish-brown to dull greenish. 
The principal component is diopsidic pyroxene. Olivine, occasionally found as phenocrysts up to $4 \mathrm{~mm}$ across, magnetite and biotite are also major constituents. Mineralogically the rocks could be referred to under the general heading of pyroxenites although as stated, they are fine-grained rocks lacking any "plutonic" features, such as might be implied by this name.

Ussing (1912) wrote a brief account of the Panernaq occurrences, describing the main rock-type as magnetite-pyroxenite, and a supplementary note (Upton, 1962) summarised what was known of these and the Tugtutôq bodies.

The contact relations against the gabbro are clearly revealed at several localities along the west coast of Panernaq. The contacts are gradational from typical pyroxenitic ultrabasic through zones of metamorphosed and metasomatised gabbro into the coarse-grained laminated olivine gabbro. Signs of textural modification and recrystallisation occur within the gabbro 4-5 $\mathrm{m}$ from the pyroxenite. The most obvious effects include an abundance of feldspathic pegmatite in the gabbro and also an increasing amount of magnetite as the ultrabasic rock is approached. Within one or two metres of the pyroxenite the modified gabbro becomes increasingly mafic and develops a vigorous flow-banding with the appearance of having been much stirred and disturbed. With the progressive loss of both feldspar and flow-banding the altered gabbro merges into the typical and finer-grained ultrabasic rock. Occasional feldspathic lumps, rich in magnetite, occurring within the main body of the pyroxenite are considered to be much altered gabbroic xenoliths. The evidence is construed as indicating that intrusive ultrabasic magma has reacted intensely with country-rock gabbro; that metasomatic introduction of iron has taken place and that actual remobilisation (re-melting) of the metasomatised gabbroic rock has occurred within 2-3 $\mathrm{m}$ of the contact and that miscegenation has proceeded within this rheomorphic zone.

The pyroxenites are texturally complex: there are facies in which auto-brecciation effects are apparent with angular chips of an earlier pyroxenite variety enclosed in a matrix of younger pyroxenite. In two of the outcrops on Panernaq low-angled layering $\left(10-15^{\circ}\right)$ is seen, dipping towards the east. The layering involves textural and mineralogical variation on a fairly fine scale with the thickness of individual layers rarely exceeding a few centimetres. There are no indications of graded-bedding or any other "sedimentary" features and the layering is apparently of a quite different kind from the gravity-controlled rhythmic layering well known from the 
larger Gardar syenites and gabbros. The pyroxenites are commonly riddled with curvilinear intersecting veins, up to $4-5 \mathrm{~cm}$ thick, producing flamboyant reticulate patterns across the exposures. The veins are often complexly zoned and are frequently pegmatoid in their central parts. Megascopic biotites are common in these veins and also occur up to several centimetres across in drusy cavities in the host pyroxenite. Euhedral crystals of amphiboles (? actinolite) and sphene also occur.

The order in which the minerals commenced crystallisation, as deduced from textures, is as follows:- olivine, followed by pyroxene, with magnetite and (phlogopitic) biotite following. In one of the Tugtutôq intrusions, barkevikitic hornblende is a relatively early constituent. Minerals of late paragenesis seen interstitially or as reaction fringes around the early olivines and pyroxenes inclúde andradite, hydro-andradite (?), perovskite, sphene, actinolite, muscovite, chlorite, serpentines, zeolites (analcite, thomsonite (?) and stilbite (?)), calcite and apatite. Biotite-actinolite-zeolite assemblages are typical of the veins which appear to represent the crystallisation products of residual and hydrous fluids.

The pyroxenes are normally colourless, with compositions close to diopside. However in at least two of the Panernaq outcrops a yellow-green, mildly pleochroic, pyroxene appears and there is evidence that this variety is of lower temperature paragenesis than the colourless diopside. Analysis shows the yellow-green pyroxene to have a relatively high content of $\mathrm{Al}, \mathrm{Ti}$ and $\mathrm{Fe}$ and that it is best described as a ferrian diopside.

Zoning and reaction relationships testify to strongly disequilibrium crystallisation. Differentiation through fractionation of early olivine and pyroxene gave rise to liquids relatively enriched in aluminium, titanium and ferric iron. The abundance of late-stage amphiboles and zeolites suggests that the residuals were low temperature hydrous fluids, not particularly alkaline in character. The typical pyroxenites are compositionally similar to mica pyroxenite described by Stewart (1964) from Qagssiarssuk where monchiquite, alnöite, mica peridotite and uncompahgrites occur as associates. They are typically undersaturated in silica with nepheline and sometimes leucite and/or kalsilite appearing in the norm. Bulk compositions are similar to those of katungites, melilite nephelinites, melanite ouachitites and some monchiquites. The fine-grained, decussate nature of the rocks, the strongly disequilibrated assemblage and the ramifying profusion of pegmatoid veinlets may all be consequences of rapid, largely adiabatic, crystallisation of a monchiquitic magma, attendant on the rapid loss of volatiles. 
References

Stewart, J. W. (1964) The earlier Gardar igneous rocks of the Ilímaussaq area, South Greenland. Unpublished Ph. D. thesis, Durham University.

Upton, B. G.J. (1962) The geology of Tugtutôq and neighbouring islands, South Greenland, Part I. Medd. Grфnland, Bd.169, Nr.8.

(1964) The geology of Tugtutô and neighbouring islands, South Greenland. Part III. Olivine gabbros, syeno-gabbros and anorthosites. Medd. Grфnland, Bd.169, Nr.3.

Ussing, N. V. (1912) The geology of the country around Julianehaab, Greenland. Medd. Grønland, Bd. 38.

\author{
PETROLOGICAL STUDIES OF SOME ALKALIC \\ AND PERALKALIC DYKE ROCKS FROM THE \\ TUGTUTÔQ-NARSSAQ AREA
}

\title{
R. Macdonald
}

The purpose of current research work on the dyke rocks and, to a lesser extent, the major Gardar intrusions of Tugtutôq and adjacent areas, is to elucidate more fully the development of the peralkine comenditic magmas. The dyke swarm through the Tugtutô region is instructive as it displays an apparently continuous series of rock-types from relatively basic microsyenites (or trachytes) to peralkalic microgranites (or comendites). The most basic rocks studied in this series are augite-fayalite microsyenites containing neither modal quartz nor normative aegirine. In more differentiated members of the swarm amphiboles of the hastingsite series become the dominant ferromagnesian minerals and modal quartz appears as an interstitial constituent. The hastingsitic amphiboles show some continuous zoning but give way abruptly with further differentiation to members of the riebeckite-arfvedsonite series. The trachytic rocks containing riebeckite-arfvedsonites show acmite in their norms and may be considered as peralkalic (in Shand's sense). With more extreme differen- 